\title{
Karabuğday Bitkisinin (Fagopyrum esculentum Moench.) Bazı Ekofizyolojik Özellikleri Üzerine Kadmiyum ve Nikel'in Etkisi
}

\author{
Sema LEBLEBİCi் $\dot{I}^{1,2 *}$ \\ ${ }^{1}$ Bilecik Şeyh Edebali Üniversitesi, Fen Edebiyat Fakültesi, Moleküler Biyoloji ve Genetik Bölümü, Bilecik, \\ TÜRKIYE \\ ${ }^{2}$ Bilecik Şeyh Edebali Üniversitesi, Biyoteknoloji Uygulama ve Araştırma Merkezi, Bilecik, TÜRKIYE
}

Geliş / Received: 03/02/2019, Kabul / Accepted: 09/10/2019

Öz

Karabuğday bitkisi (Fagopyrum esculentum Moench.) Polygonaceae (Kuzukulağıgiller) familyasından Fagopyrum cinsine ait tek yıllık otsu bir bitki türüdür. Karabuğday tuzluluk, sicaklık değişimi gibi abiyotik faktörde meydana gelen değişimlere dayanıklı bir türdür. Abiyotik faktörlerden en önemlilerinden biri ise ortamda ağır metallerin varlığıdır. Bu çalışmada $\mathrm{Cd}$ ve Ni metallerinin karabuğday bitkisinin tohum çimlenme oranı, kök uzunluğu, kök ve gövde taze-kuru ağırlığı, kök ve gövde biyokütlesi ve Cd ve Ni tolerans indeksine etkisi araştırılmıştır. Farklı konsantrasyonlarda uygulanan $\mathrm{Cd}$ ve Ni kontrol grubu ile karşılaştırılarak elde edilen sonuçlar değerlendirilmiştir. Elde edilen sonuçlara göre çimlenme oranı azalmış ancak önemli bir azalma görülmemiştir. Cd ve Ni uygulanan örneklerde konsantrasyon artışına bağlı olarak kök uzunluğu, kök ve gövde taze-kuru ağırlığı ve biyokütle miktarında azalma olduğu tespit edildi. Karabuğday bitkisinin incelenen ekofizyolojik parametrelerinde Cd'un Ni metaline göre daha etkili olduğu belirlendi.

Anahtar Kelimeler: Karabuğday, abiyotik stres, ağır metal, çimlenme, fide gelişimi

\section{The Effect of Cadmium and Nickel on Some Ecophysiological Characteristics of Buckwheat (Fagopyrum esculentum Moench.)}

\begin{abstract}
Buckwheat (Fagopyrum esculentum Moench.) is an annual herbaceous plant species belonging to the genus Fagopyrum from the Polygonaceae family. Buckwheat is resistant to changes in abiotic factor such as salinity, temperature change. One of the most important abiotic factors is the presence of heavy metals in the environment. In this study the effect of $\mathrm{Cd}$ and $\mathrm{Ni}$ metals on seed germination rate, root length, root and stem fresh-dry weight, root and stem biomass and $\mathrm{Cd}$ and Ni tolerance index of buckwheat plant were investigated. Different concentrations of $\mathrm{Cd}$ and Ni samples were compared with the control group. According to the results, seed germination rate decreased but there was not much decrease. In the $\mathrm{Cd}$ and $\mathrm{Ni}$ applied samples, it was determined that as the concentration increased, the root length, root and stem fresh-dry weight and the amount of biomass decreased. It was determined that $\mathrm{Cd}$ was more effective than $\mathrm{Ni}$ metal in the ecophysiological parameters examined of buckwheat plant.
\end{abstract}

Keywords: Buckwheat, abiotic stress, heavy metal, germination, seedling 


\section{Giriş}

Karabuğday, (Fagopyrum esculentum Moench.), Polygonaceae (Kuzukulağıgiller) familyasından Fagopyrum cinsine ait tek yıllık otsu bir bitki türüdür (Guo vd., 2007; Kan, 2014). Kökeni Asya olan Karabuğdayın kültürünün yapıldığı ülkeler arasında; Rusya, Çin Halk Cumhuriyeti, Amerika Birleşik Devletleri, Kanada, Kuzey Fransa, Almanya, İtalya, Slovakya, Polonya ve Türkiye yer almaktadır.

Karabuğday büyüme ve gelişmesini kısa sürede tamamlayan; lifli, kazık kök sistemine sahip bir kültür bitkisidir (Bjorkman, 2010; Yavuz, 2014). Kimyasal kompozisyonu ve görünüşü ile tahıl tanelerine benzetilmektedir, fakat tahıllarla hiç bir akrabalığı yoktur (Guo vd., 2007; Acar, 2009; Acar vd., 2011). Karabuğdayı tahıllardan ayıran temel yapısal farkl1l1k dikotil bir bitki olması ve yüksek rakımlarda kısa sürede gelişmeye adapte olabilme özelliğinin bulunmasıdır (Dizlek vd., 2009; Kan, 2014).

Yabancı tozlaşan bir bitki olan karabuğdayın çiçeklenmesi vejetasyon döneminde uzun bir süre (30-45 gün) devam etmektedir (Guo vd., 2007; Süzer, 2007). Tohumları üçgen şeklinde ve köşelidir; tohumun rengi, büyüklüğü ve şekli bitkinin çeşitlerine göre değişiklik göstermektedir.

Karabuğday, iklim isteği bakımından kısmen seçici bir bitki türüdür, serin ve nemli bölgelerde çok iyi yetişmektedir. 8-14 hafta gibi kısa bir vejetasyon süresinin olması ve sıcaklık isteğinin düşük olması sebebi ile kuzey enlemlerde ve yüksek yerlerde (0-4200 m) yetişebilmektedir. İklim şartları uygun olduğu müddetçe, topraktan talebi oldukça azdır ve hemen hemen her çeşit toprakta yetişebildiği için verimli olmayan bölgelerde ve marjinal topraklarda yetiştirilmektedir. pH'1 4-6 arsında değişen ve verimli olmayan asit topraklara toleransı iyidir. (Güneş, 2012).

Son yıllarda Karabuğday'ın ekim alanları, dünyanın farklı ülkelerinde önemli düzeyde artmıştır. Bunun en büyük sebebi karabuğdayın çok fazla kullanım alanına sahip olmasından dolayı ekonomik değerinin yüksek olmasıdır. Karabuğday dünyada fonksiyonel gıda olarak üretilen ürünler arasında yer almaktadır. $\mathrm{Bu}$ nedenle karabuğday ürünleri ilaç ve gıda olarak çift kullanımlı ürünlerdir ve insan vücudunda kronik hastalıklarda ilginç etkileri vardır (Rajbhandari, 2004; Crista ve Smietana, 2008; Erbaş vd., 2008, Peng vd., 2012). Özellikle karabuğday tohumları buğday glutenine hassas olan çölyak hastaları için önemli bir gıda kaynağıdır ve bu nedenle insan beslenmesinde kullanılabilmektedir (Güneş, 2012; Skrabanja vd., 2001, Yavuz, 2014). Ayrıca karabuğday insan ve hayvan sağlığ üzerinde etkili olan bazı sekonder metabolitleri içermektedir. En fazla bulunan sekonder metabolit "Rutin" adı verilen bir flavonal glikosittir. Bu madde bakımından en zengin bitki karabuğdaydır. Serbest radikalleri yakalama özelliğinden dolayı güçlü bir antioksidandır (Watanabe vd., 1997; Rajbhandari, 2004; Christa ve Smietana, 2008). Aynı zamanda karabuğday yumurta tavukçuluğunda, küçük ve büyükbaş hayvan yetiştiriciliğinde yem olarak, çoğu ülkede ise bal üretiminde nektar kaynağı olarak da kullanılmaktadır (Güneş, 2012).

Bitkilerde büyüme ve gelişmeyi olumsuz etkileyen, ürün kalitesinin ve miktarının azalmasına sebep olan, ilerleyen süreçte bitkinin veya organlarının ölümüne yol açan önemli metabolik ve fizyolojik değişimlere stres adı verilmektedir (Haktanır ve Arcak, 1998). Stresin ortaya çıkmasında en önemli 
etkenler biyotik ve abiyotik ekolojik faktörlerde meydana gelen değişikliklerdir. Kuvvetli 1şık, ultraviole, yüksek ve düşük sıcaklıklar, don olayı, kuraklık, tuzluluk, ve yetersiz oksijen gibi birçok abiyotik stres faktörü vardır (Hirayama ve Shinoza, 2010). $\mathrm{Bu}$ faktörlerin en önemlilerinden biri ise ağır metal stresidir. Günümüzde, ağır metaller su, hava ve toprak gibi ortamlarda birikerek çeşitli ekosistemlerde bulunan canlıların yaşamını tehdit eden önemli bir çevre sorunu halini almıştır. Ayrıca endüstriyel faaliyetler ve sanayileşme başta olmak üzere motorlu taşıtların egzozları, kentsel atıklar, tarımda bilinçsiz gübreleme ve ilaç kullanımı ile volkanik faaliyetler sonucu ağır metaller çevreye yayılmakta; bitkilerin doku ve organlardaki aşırı birikimi ile generatif ve vejetatif organlarının gelişimini olumsuz yönde etkilemektedir (Madhava ve Sresty, 2000; Waisberg vd., 2003; Gür vd., 2004). Düşük konsantrasyonlarda bile toksik veya zehirleyici olan ve nispeten yüksek yoğunluğa sahip metaller, kolay kolay girdikleri organizmadan atılamazlar.

Mikro besin elementi olan nikel toprakta 100 mg/kg'ın üzerinde olduğu durumda bitkilerde toksik etki oluşturmaktadır (Yıldız, 2001). Kanalizasyon atıklarının kullanıldığ alanlarda yaygın şekilde nikel toksisitesi ile karşılaşılmaktadır. Yüksek miktarlarda nikel içeren topraklarda yetiştirilen bitkilerde zehirlenmeler ortaya çıkmaktadır. Bu nedenle toprakların kalsiyum ve potasyum ile gübrelenmesi nikelin zehir etkisini önlemektedir. Buna karşıllk fosfatlı gübrelerin nikelin zehir etkisini artırdığ bilinmektedir (Kantarc1, 2000; Kaçar ve Katkat, 2010).

Kadmiyum elementi ekosistemde en tehlikeli ağır metallerden biri olup organizmaların biyolojik fonksiyonları için hayati gerekliliği yoktur. Önemli bir kirletici olmasının nedeni ise çok düşük dozlarda bile toksik olması ve biyolojik yarı ömrünün uzun olmasıdır. Toprakta ekstrakte edilebilir kadmiyum konsantrasyonu $1 \mathrm{mg} / \mathrm{kg}$ 'dır (Y1ldız, 2001). Topraktaki kadmiyum alınımını iki önemli faktör etkilemektedir. Bunlar toprağın pH'1 ve toprağın var olan kadmiyum konsatrasyonudur. Toprağın pH'ı arttıkça bitki dokularına kadmiyum alımı azalır. Topraktaki uygun kimyasal, fiziksel ve biyolojik şartlar altında $\mathrm{Cd}$ konsantrasyonu arttıkça Cd alımı da artmaktadır. Kadmiyumun bitki metabolizmasında çok önemli zararlara ve oksidatif strese neden olduğu birçok çalışmada belirtilmiştir (Vitoria vd., 2001; Benavides vd., 2005; Gratao vd., 2005). Bitkilerde kadmiyum çeşitli fizyolojik ve biyokimyasal süreçleri bozmakta, hücre ölümüne ve büyümenin engellenmesine sebep olmaktadır (Toppi ve Gabrielli, 1999; Sandalio vd., 2001; Guo vd., 2009; Tran ve Popova, 2013).

Sağlıklı bir bitkinin meydana gelmesinde tohum çimlenme aşaması ve erken fide gelişim dönemi oldukça önemlidir. Buradan yola çıkarak çalışmamızda kadmiyum ve nikelin; sekonder metabolit içeren, sadece vejetasyon döneminde değil her dem yeşilliğini koruyan, birçok kullanım alanı bulunan ve stres farktörlerine karşı dayanıklı bir bitki türü olan karabuğday bitkisinde meydana getirdiği ekofizyolojik etkiler çimlenme ve fide gelişim parametreleri ile belirlenmiştir.

\section{Materyal ve Metot}

Çimlenme deneylerinde tescilli Güneş çeşidine ait Karabuğday tohumları kullanılmıştır. Tohumlar rastgele seçilmiş ve ekimden önce sterilizasyon işlemine tabi tutulmuştur. Sterilizasyon işleminde 
tohumlar \%10'luk $\mathrm{NaOCl}$ içinde 10 dakika bekletilip ardindan $3 \mathrm{kez}$ distile su ile y1kanarak sterilizasyon işlemi gerçekleştirilmişitir (Jabeen ve Ahmad, 2012).

Tohumların ekim işlemi, kontaminasyon riskini en aza indirmek için steril kabinde ve tamamı otoklavda steril edilmiş laboratuvar malzemeleri ile gerçekleştirilmiştir. Çimlenme deneyleri için $\mathrm{Cd}$ hem de $\mathrm{Ni}$ için $50,75,100$ ve 150 ppm olmak üzere 4 farklı çözelti hazırlanmıştır. Kontrol grubu için ise distile su kullanılmıştır. Tohumlar 2'şer kat kurutma kağıdı üzerine yerleştirilmiş, $12 \mathrm{~cm}$ çapındaki petri kaplarına 3 tekrarlı olarak ekilmiştir. Her tekrarda 100 adet tohum kullanılmış ve her bir petri kabı $6 \mathrm{ml}$ çözelti ile sulanmıştır. Sulama işlemi 3 günde bir tekrarlanmıştır. Ekimi yapılan tohumlar 16/8 saat fotoperiyot ve $25 \pm 2{ }^{\circ} \mathrm{C}$ 'ye ayarl iklimlendirme odasında 21 gün süreyle bekletilmiştir. Radikulanın kurutma kâğıdına değdi an çimlenmenin başlangıcı olarak kabul edilmiş ve çimlenme başladıktan sonra her

\section{Bulgular}

\section{1. Çimlenme oranı}

Çalışmada dört farklı konsatrasyonda $(50,75$, 100 ve $150 \mathrm{ppm}) \mathrm{Cd}$ ve $\mathrm{Ni}$ uygulanan karabuğday tohumlarının çimlenme oranları karşılaştırılmış, her iki ağır metal uygulamasında da konsantrasyon artışına bağlı olarak çimlenen tohum sayısında azalma olduğu belirlenmiştir $(p<0.05)$. Cd ile $\mathrm{Ni}$ sonuçları karşılaştırıldığında ise Cd'un tohum çimlenmesi üzerine olumsuz etksinin Ni'e göre daha fazla olduğu görülmüştür (Tablo 1).

\subsection{Kök ve gövde uzunlukları}

Fidelerin kök ve gövde uzunlukları karşılaştırıldığında gerek $\mathrm{Cd}$ gerek $\mathrm{Ni}$ uygulamasında konsantrasyon artışına bağlı gün çimlenen tohum sayıları kaydedilmiştir. 21 günün sonunda çimlenen tohumların çimlenme oranı (\%), kök ve gövde uzunluğu, kök ve gövde yaş-kuru ağırlığı ölçülmüş; tohum canlilık indeksi, kök ve gövde biyokütlesi, $\mathrm{Cd}$ ve $\mathrm{Ni}$ tolerans indeksleri olmak üzere altı farklı ekofizyolojik parametre hesaplanmıştır (Böhm, 1979; Işık ve Çalıseki, 2017; Kayaçetin vd., 2018).

Çimlenme Oranı: ((Çimlenen tohum sayıs1/Toplam tohum say1s1) $x \quad 100)$ (Kayaçetin ve ark., 2018).

Tohum Canlılık İndeksi: ((Kök uzunluğu + gövde uzunluğu) $\mathrm{x}$ çimlenme oranı) (Kayaçetin ve ark., 2018).

Kök Biyokütle: (Kök kuru ağırlığıxpetri kabının alanı) $/ 10^{-8}$ (Işık ve Çalıseki, 2017).

Gövde Biyokütle: (Gövde kuru ağırlığı x petri kabının alanı)/108 (Işık ve Çalıseki, 2017).

Elde edilen sonuçlar One-way ANOVA (SPSS 21.0) testi ile istatistiksel olarak değerlendirilmiştir.

olarak kök ve gövde uzunluklarının azaldığ tespit edilmiştir. Kontrol örneklerinde kök uzunluğu $13.37 \mathrm{~cm}$, gövde uzunluğu ise 5.93 cm olarak tespit edilmiştir. $\mathrm{Cd}$ ve $\mathrm{Ni}$ konsantrasyonu arttıkça hem kök uzunluğu hem de gövde uzunluğu azalmıştır. 150 ppm Cd uygulanan örneklerde kök uzunluğu 3.42 $\mathrm{cm}$, gövde uzunluğu ise $3.21 \mathrm{~cm}$ 'ye azalmıştır. Aynı şekilde Ni uygulanan örneklerde ise kök uzunluğu 4.89 cm'ye, gövde uzunluğu ise $4.16 \mathrm{~cm}$ 'ye azalmıştır. Her iki ağır metal uygulamasında 100 ve 150 ppm'de kök ve gövde uzunluklarında önemli bir azalmanın olduğu belirlenmiştir $(\mathrm{p}<0.05)$. Ayrıca erken gelişim evresinde fidelerin kök ve gövde gelişiminde Cd'un olumsuz etkisinin Ni'den daha fazla olduğu görülmüştür (Şekil 1). 
Tablo 1. Cd ve Ni uygulanan tohumların çimlenme oranları $(\%)(* p<0.05)$

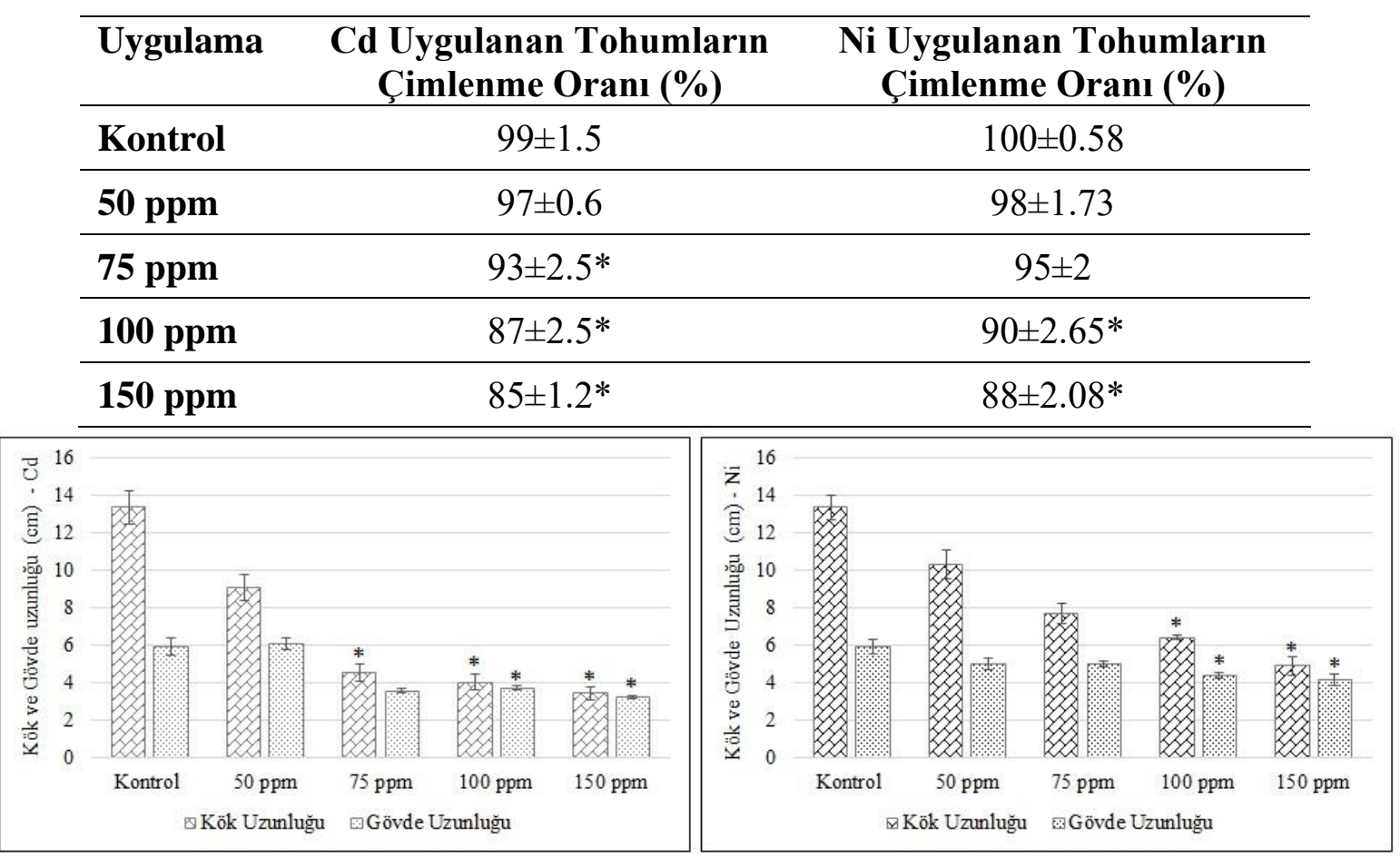

Şekil 1. Cd ve Ni uygulanan Karabuğday fidelerinin kök ve gövde uzunlukları $(\mathrm{cm})\left({ }^{*} \mathrm{p}<0.05\right)$

3.3. Cd ve Ni uygulamasının kök ve gövdelere ait taze-kuru ağırlıklar, biyokütle miktarına etkisi

Cd ve Ni uygulanan bitki örnekleri ve kontrol grubu karabuğday örneklerinin kökleri alınmış ve taze-kuru ağırlıkları ölçülmüştür. Kontrol örneklerinde kök taze ağırlığ $0.41 \mathrm{~g}$, kuru ağırlık ise 0.078 g'dır. Farklı konsantrasyonlarda $\mathrm{Cd}$ ve $\mathrm{Ni}$ uygulandiğ 1 zaman konsantrasyon artışına bağlı olarak kök taze ve kuru ağırlıklarında azalma olduğu belirlenmiştir. 150 ppm Cd uygulandığında kök taze ağırlığg $0.05 \mathrm{~g}$, kuru ağırlığ1 $0.031 \mathrm{~g}$ olarak tespit edilmiştir. Aynı şekilde 150 ppm $\mathrm{Ni}$ uygulanan örneklerin kök taze ağırlı̆̆1 $0.174 \mathrm{~g}$ iken kuru ağırlığg $0.053 \mathrm{~g}$ olarak tespit edilmiştir. Karabuğday fidelerinin kök taze ve kuru ağırlıklarının Ni'e kıyasla Cd'un artan konsantrasyonlarından daha fazla etkilendiği, özellikle 150 ppm Cd uygulamasında taze ve kuru ağırlığın kontrole göre önemli derecede azaldığı tespit edilmiştir (Şekil 2, p<0.05).
Gövdeye ait taze ve kuru ağırlık sonuçları da kök ile benzerlik göstermektedir. Karabuğday örneklerinin gövde taze ve kuru ağırlık sonuçlarına Şekil 3'de yer alan karabuğday örneklerinin gövde taze ve kuru ağırlık sonuçlarına göre, kontrol grubu taze gövde ağırlığ1 $1.913 \mathrm{~g}$, kuru gövde ağırlığ $0.303 \mathrm{~g}$ olarak belirlenmiştir. 150 ppm $\mathrm{Cd}$ uygulandığında taze ağırlığın 0.909 g, kuru gövde ağırlığ 1 ise 0,176 gram olarak tespit edilmiştir. 150 ppm Ni uygulanan örneklerde taze gövde ağırlığ1 $1.367 \mathrm{~g}$, kuru gövde ağırlığı ise $0.172 \mathrm{~g}$ olduğu belirlenmiştir. Dolayısı ile konsantrasyon arttıkça gövde ağırlığıda azalmaktadır. Ni uygulamasında artan konsantrasyona bağlı olarak gövde taze ve kuru ağırlığında bir azalma olsa da $\mathrm{Cd}$ uygulamasında daha fazla azalma olduğu ifade edilebilir. 

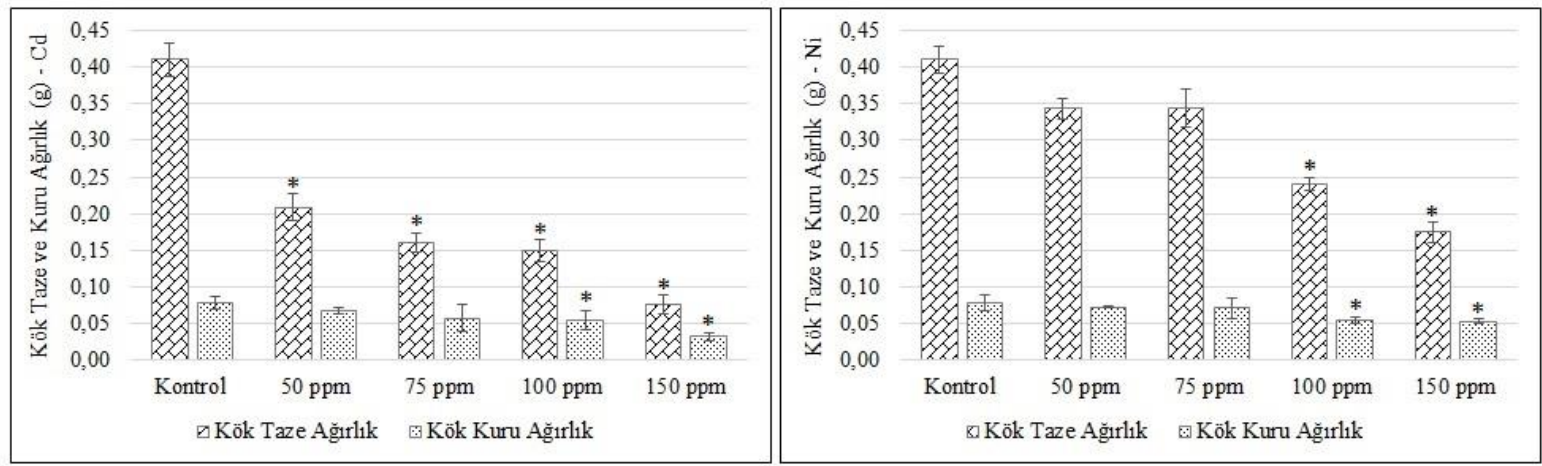

Şekil 2. Cd ve Ni uygulanan Karabuğday fidelerinin köklerine ait taze ve kuru ağırlıklar (g) $(* \mathrm{p}<0.05)$
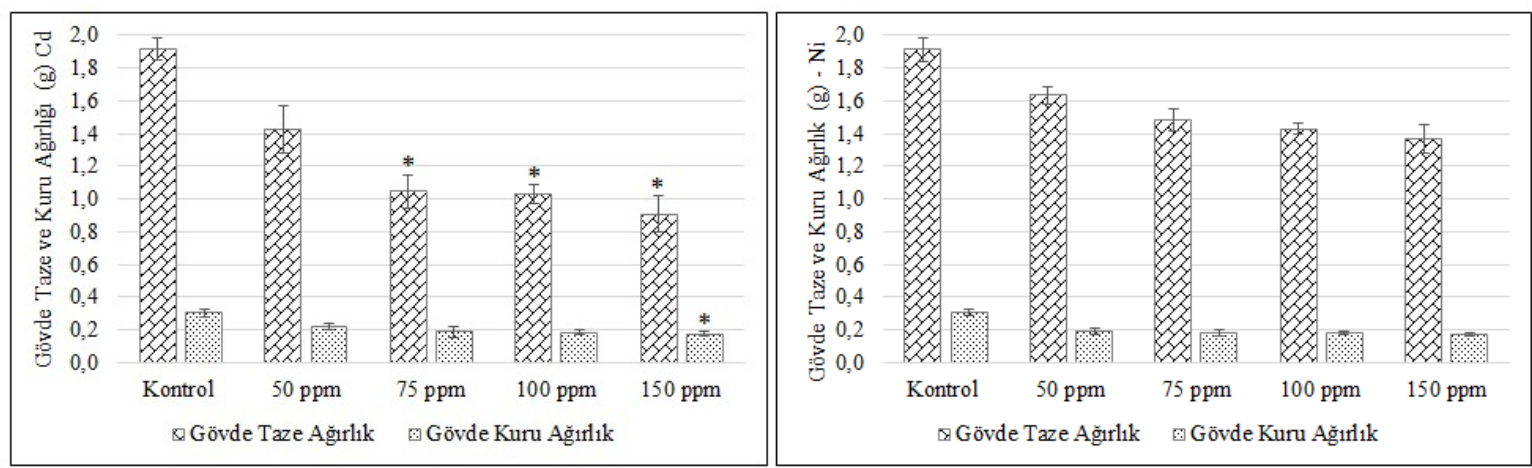

Şekil 3. Cd ve Ni uygulanan Karabuğday fidelerinin gövdelerine ait taze ve kuru ağırlıklar (g) $(* \mathrm{p}<0.05)$
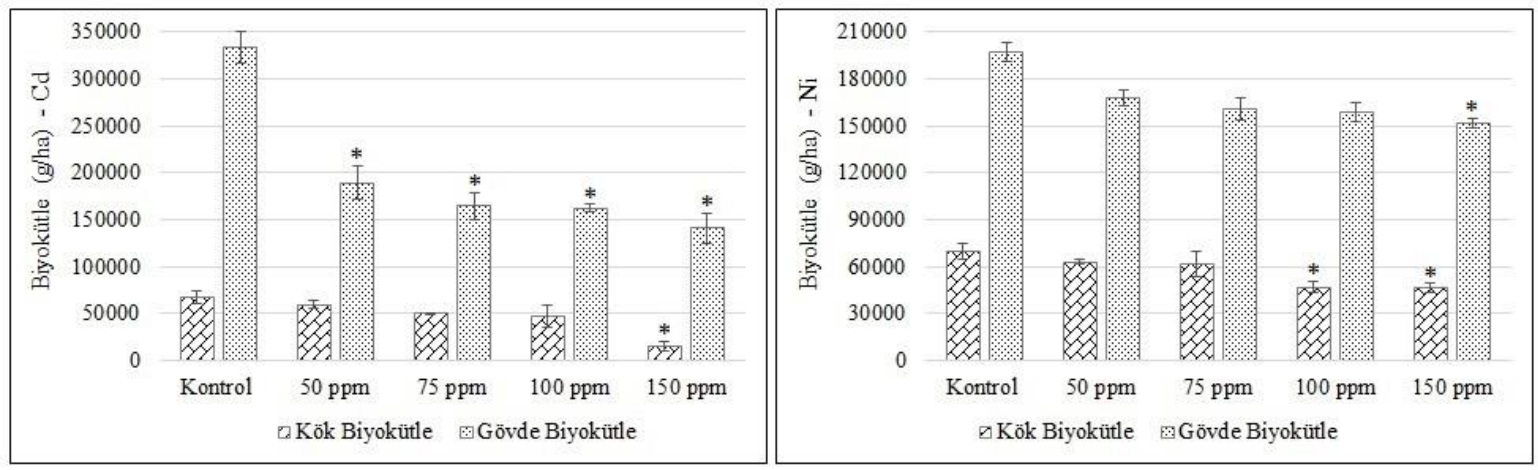

Şekil 4. Cd ve Ni uygulanan Karabuğday fidelerinin kök ve gövde biyokütleleri (g/ha) $(* p<0.05)$

Çalışmamızda $\mathrm{Cd}$ ve $\mathrm{Ni}$ uygulamasının karabuğday bitkisi kök ve gövde biyokütlesi üzerine etkisi araştırılmış ve her iki ağır metalde konsantrasyona bağlı olarak farklı sonuçlara rastlanmıştır. Kök ve gövde biyokütlelerinde $\mathrm{Cd}$ uygulamasında kontrole göre azalma tespit edilmiştir $(p<0.05)$. Ni

uygulamasında Cd'a göre biyokütle düşüşü daha azdır. Kontrol grubunda biyokütle değerleri incelendiğinde kök biyokütlesi $68202.48 \mathrm{~g} / \mathrm{ha}$ iken gövde biyokütlesi $265188.69 \mathrm{~g} / \mathrm{ha}$ olarak belirlenmiştir. Farklı konsantrasyonlarda Cd uygulandığında 150 ppm değerde kök biyokütlesi $15378.55 \mathrm{~g} / \mathrm{ha}$, 
gövde biyokütlesi $140641.43 \mathrm{~g} / \mathrm{ha}$ olduğu görülürken (Şekil 4), $150 \quad$ ppm $\quad \mathrm{Ni}$ uygulandığında ise kök biyokütlesi 46428.23 $\mathrm{g} / \mathrm{ha}$ iken gövde biyokütlesi $151589.87 \mathrm{~g} / \mathrm{ha}$ dır (Şekil 4).
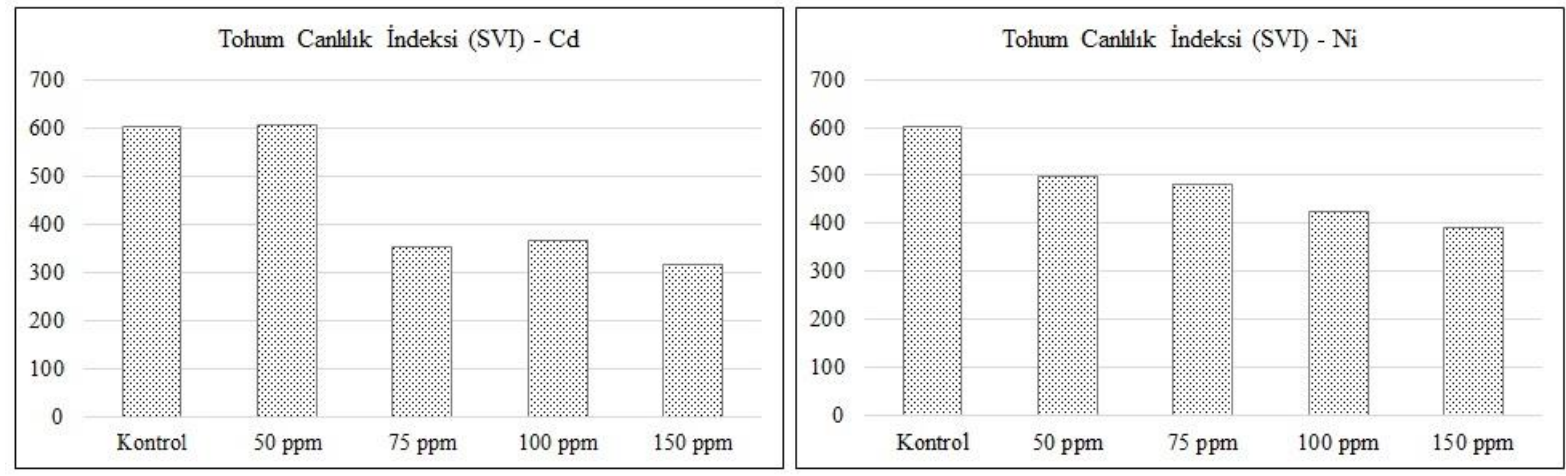

Şekil 5. Cd ve Ni uygulanan Karabuğday tohumlarının canlılık indeksi
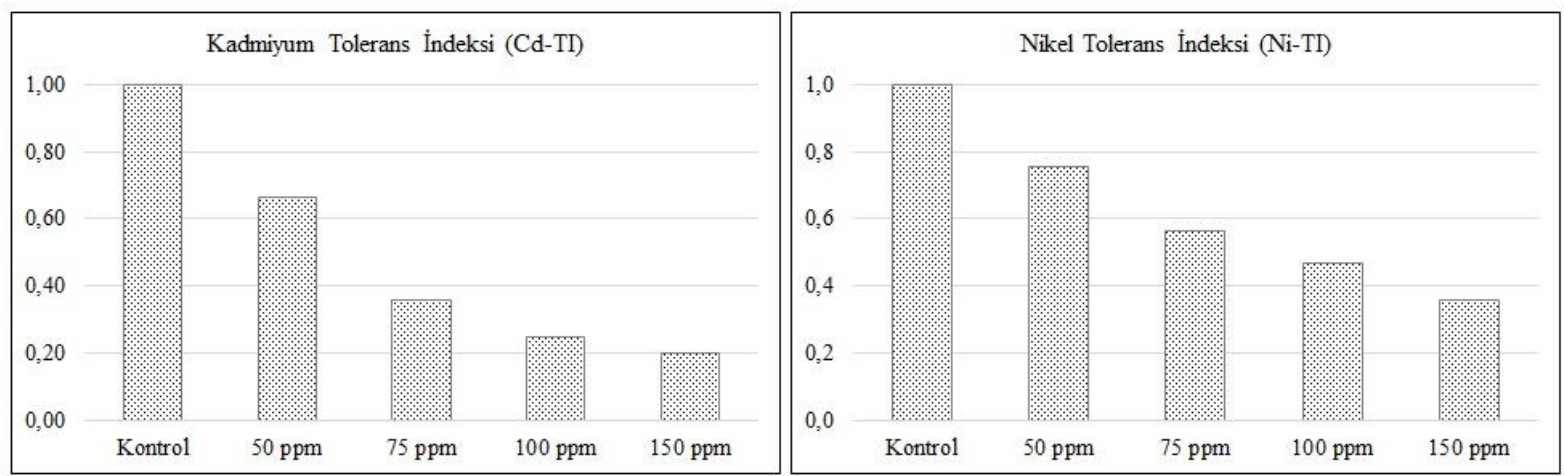

Şekil 6. Karabuğday bitkisinin Cd ve Ni tolerans indeksi

Şekil 5 incelendiğinde kontrol grubunun canlılık indeksi 601.06 iken $\mathrm{Cd}$ ve $\mathrm{Ni}$ uygulandığında konsantrasyon arttıkça canlı kalabilme oranının azaldığı görülmektedir. $\mathrm{Cd}$ ve Ni uygulanan Karabuğday tohumlarının canll1lk indeksleri incelendiğinde özellikle düşük konsantrasyonlarda tohum canlılığına olan etki oldukça düşüktür. Çünkü Ni aynı zamanda bir mikro besin elementidir. $\mathrm{Cd}$ da ise özellikle 75, 100 ve 150 ppm'de tohum canlılık indeksi üzerine negatif etkisinin fazla olduğu tespit edilmiştir. Bu durum tohum çimlenme oranı (\%) sonuçlarını destekler niteliktedir.

Ağır metal tolerans indeksi, bitkinin herhangi bir ağır metale göstermiş olduğu dayanma sınırını gösteren bir parametredir. Bitkilerin herhangi bir stres faktörüne karşı göstermiş olduğu tolerans türden türe hatta aynı türün çeşitlerinde farklılık göstermektedir. Çalışmada Karabuğday bitkisinin fide gelişiminde Ni toleransinin Cd'a göre daha yüksek olduğu tespit edilmiştir. Her iki metalde artan konsantrasyon ile tolerans indeksinin ters bir korelasyon gösterdiği belirlenmiştir.

\section{Sonuç ve Tartışma}

Bitkiler yaşadıkları ortamda meydana gelecek biyotik veya abiyotik faktörlere karşı direnç gösteremedikçe yaşamlarını sürdüremezler. Dolayısı ile stres faktörlerinin etkilerinin ve bu etkilere karşı koyma mekanizmalarının bilinmesi bitkilerden faydalanma ve onları 
yaşatma adına oldukça önemlidir. Tohum aşamasından itibaren çimlenmeyle başlayacak bitki gelişim evreleri meyva verip neslin devamını sağlayacak süreçler ile tamamlanmaktadır. Tohum çimlenmesi, bitkinin yaşam döngüsünün ilk ve en kritik safhalarından biri olup (Guan vd., 2009) hormonal ve çevresel olaylara karşı oldukça duyarlıdır (Finch-Savage ve LeubnerMetzger, 2006). Ağır metal konsantrasyonu arttıkça çimlenme oranının, kök ve sürgün gelişiminin önemli ölçüde engellendiği bilinmektedir (Gür vd., 2004). Bitkiler için çok düşük miktarlarda yararlı etkileri olduğu bildirilen nikelin (Mishra ve Kar, 1974) aşırı konsatrasyonlarının bitkilerde olumsuz etkilerinin olduğu belirtilmektedir. Ebru (2014) yapmiş olduğu çalışmada mısır tohumlarına 80 ve $160 \mathrm{mg} / \mathrm{L}$ Ni uygulamış; 80 mg/L.'de çimlenme oranının etkilenmediğini ancak $160 \mathrm{mg} / \mathrm{L}$.'de kontrol grubuna göre çimlenme oranında azalmanın olduğunu bildirmiştir. Liu ve arkadaşları (2012) yapmış oldukları bir çalışmada halofit bir bitki olan Suaeda salsa'ya çaşitli konsantrasyonlarda $\mathrm{Cd}^{+2}$ iyonu uygulamışlar ve sonuçta çimlenme parametreleri ile büyüme inhibisyon $\begin{array}{llll}\text { indekslerinin, } & 0.1 & \mathrm{mg} / \mathrm{L} & \mathrm{CdCl}_{2}\end{array}$ konsantrasyonunda önemli ölçüde azaldığını $(\mathrm{p}<0.05) ; \quad \operatorname{artan} \quad \mathrm{Cd}^{+2}$ konsantrasyonuyla inhibisyon etkisinin arttığını göstermişlerdir. Oryza sativa ile yapılan bir çalışmada düşük $\mathrm{Cd}$ konsantrasyonlarının çimlenme üzerine oldukça düşük etkisinin olduğu fakat yüksek konsantrasyonlarda çimlenme endeksi, canlılık indeksi ve kök uzunluğunun azaldığ 1 belirlenmiştir (He vd., 2008). Wang vd. (2003) yaptıkları çalışmada topraktaki uygun kimyasal, fiziksel ve biyolojik şartlar altında $\mathrm{Cd}$ konsantrasyonu arttıkça $\mathrm{Cd}$ alımının da arttığını belirtmişlerdir. Karabuğday ile literatürde yapılmış metal ile ilgili çalışmalar bulunmakla birlikte $\mathrm{Ni}$ ve $\mathrm{Cd}$ ile çalışmaya rastlanmamışır. Liu vd. (2009) çalışmalarında
20-120 $\mathrm{mg} / \mathrm{L} \quad \mathrm{Cu}^{+2} \quad$ konsantrasyonlarının tohum çimlenmesini arttırdığ 1 ancak bu konsantrasyonların fide gelişimini azalttığını belirtmişlerdir. Çalışmamızda da $\mathrm{Cd}$ ve $\mathrm{Ni}$ uygulamasının çimlenmeye çok büyük oranda etkisi olmaz ken fide gelişimini önemli ölçüde etkilediği tespit edilmiştir. Liu vd. (2009) çalışmasında daha yüksek konsantrasyonlarda Cu'un çimlenmeyi inhibe ettiği ifade edilmiştir.

Çimlenme aşamasında kök uzaması bir çok faktörden etkilenir. Tohumdan ilk çıkan köke radikula, sürgüne ise plumula adı verilir. Radikula ve plumula gelişimini etkileyen tüm faktörler bitkinin erken gelişim evresi üzerinde de etkilidir. $\mathrm{Bu}$ faktörlerin en önemlileri arasında sicaklık, $\mathrm{pH}$, tuz, besin yetersizliği ve metal varlığı sayılabilir (Jamil vd. 2006; Laghmouchi vd., 2017; Kranner ve Colville, 2011). Pirinç bitkisi ile yapılan bir çalışmada kadmiyum stresinin özellikle radikula ve plumula büyümesini önemli ölçüde engellediği tespit edilmiştir (Liu vd., 2012). Ayrıca kök uzunluğu ve amilaz aktivitesinin artan kadmiyum seviyesi ile belirgin bir şekilde azaldı ̆̆ vd., 2008). Yüksek konsantrasyonlardaki ağır metallerin büyümede zararlı etkileri diğer metaller ile de görülmektedir. Nikelin yüksek konsantrasyonları, bitkilerde çimlenme aşamasından başlayarak bitkinin büyüme ile gelişmesinde toksik etki yapar. Ayrıca yüksek konsantrasyonlarda kök büyümesini ve sürgün gelişimini sınırlamaktadır (Marschner, 1995). Soudek vd. (2010) kurşun, nikel, bakır, çinko, kadmiyum, kobalt, arsenik ve krom ağır metallerinin $0.01,0.05,0.1,0.5$ ve 1 mM'lık konsantrasyonlarını keten (Linum $\begin{array}{lll}\text { usitatissimum } & \text { L.) } \quad \text { tohumlarına }\end{array}$ uygulamışlardır. Ağır metal konsantrasyonlarının artışına paralel olarak çimlenen tohum sayısında ve kök uzunluğunda azalma olduğunu 
belirlemişlerdir. Ayrıca yapılan başka bir çalışmada artan nikel konsantrasyonuna bağlı olarak çimlenen tohumların anlık enerji ihtiyacının karşılanmasında nişastanın glikoza, proteinlerin aminoasitlere ayrilmasında etkili olan $\alpha$-amilaz ve proteaz aktivitelerinin inhibe edildiği; buna bağlı olarak kök ve sürgün büyümesinin azaldığ belirtilmiştir (Ashraf vd., 2011). Karabuğday ile yapılan bir metal çalışmasında elde edilen sonuçlara göre $\mathrm{Pb}$, düşük konsantrasyonlarda kök büyümesini indüklerken yüksek konsantrasyonlarda inhibe ettiği, inhibe olma oranının varyeteler arasında farklılık gösterdiği tespit edilmiştir. Aynı zamanda klorofil ve protein içeriği farklı derecelerde azalırken membran permeabilitesinin arttığını ifade etmişlerdir (Liu vd., 2006). Çalışmamızda da $\mathrm{Cd}$ ve Ni uygulamasının konsantrasyona bağlı olarak kök uzunluğunu azalttığı, Cd uygulamasının Ni den daha fazla etkin olduğu belirlenmiştir.

Ağır metallerin tohumlar üzerindeki temel etkileri çimlenme, düşük kök ve sürgün uzaması, kuru ağırlıktaki azalma şeklinde kendini gösterir (Munzuroğlu, 2002). Düşük Ni seviyeleri bazı bitki türlerinin büyümesine katkıda bulunabilir, ancak bunun nedeni tam olarak bilinmemektedir (Nasr, 2013). İki ayçiçeği çeşidinde (Hysun-33 ve SF-187) Ni ile yapılan bir çalışmada tohumlara sırası ile 10, 20, 30, 40, 50 ve $60 \mathrm{mg} \mathrm{L}^{-1} \mathrm{Ni}$ uygulamas1 yapılmış ve artan konsantrasyona bağlı olarak maksimum çimlenme oranı, taze-kuru sürgün ve kök ağırlıklarının azaldığı belirlenmiştir. Ayrıca Hysun-33 çeşidinin Ni toleransının SF-187'den daha yüksek olduğu yani Ni'den daha az etkilendiği tespit edilmiştir (Ashraf, 2011). Yapılan bir çalışmada 30 gün boyunca güve otu, ayçiçeği, hint fasulyesi ve karabuğday bitkisine $0,50,100,200$ ve 400 mg $\mathrm{L}^{-1} \mathrm{~Pb}$ uygulanmış; tüm türlerin kök, sürgün ve tüm bitkinin kuru maddesinde belirgin azalma olduğu belirtilmiştir. Pb'den en az etkilenen bitki türünün güve otu, ayçiçeği ve hint fasulyesinin orta derece toleranslı, karabuğdayın ise en hassas tür olduğu belirlenmiştir (Alves vd., 2016). Kalay madeni atıklarının fitotoksik etkisinin araştırıldığı bir çalışmada ise $\mathrm{Cd}$ ve $\mathrm{Cu}$ uygulanan karabuğday bitkisinin $\mathrm{Cd}$ 'den daha fazla etkilendiği ve yüksek miktarda Cd'nin kök ve sürgün taze-kuru ağırlığında azalmaya neden olduğu belirtilmiştir (Franzaring, 2018). Ayrıca Liu vd. (2009) çalışmasında artan $\mathrm{Cu}$ konsantrasyonuna bağlı olarak gelişen bitkinin taze ağırlığının ve kök büyümesinin azaldığını tespit etmişlerdir. Klorofil ve çözülebilir protein içeriği de önce artmış sonra azalmıştır. (Liu, 2009). Karabuğdayın fide gelişimi üzerine $\mathrm{ZnO}$ ve $\mathrm{CuO}$ nanopartikülleri ile yapılan bir çalışmada, 2 ve $4 \mathrm{mg} \mathrm{L}^{-1}$ uygulamalarının kök büyümesini kontrole göre önemli ölçüde azalttığ1 belirlenmiştir (Sooyeon, 2013a). Çalışmamızda da fide gelişimi sırasında oluşan bitkinin yaş-kuru ağırlığının konsantrasyona bağlı olarak azaldığı tespit edilmiştir.

Yeşil bitkilerin fotosentez ile güneş enerjisini kimyasal enerjiye dönüştürüp depolaması ile oluşan biyolojik madde kütlesine biyokütle denir (Tziourtzioumis vd., 2009). Karabuğgday bitkisinin özellikle P ile kirlenmiş topraklarda diğer bitkilere göre daha yüksek biyokütle üretkenliğinin olduğu, birçok kozmopolit özellikte bölgeye adapte olabileceği ve bu özelliği ile fitoremediatör bitki adayı olduğu belirtilmiştir (Tamura vd., 2005). Yapılan bir çalışmada yüksek konsantrasyonlarda $\mathrm{Ni}$ uygulamalarında yüksek biyokütle verimliliğine sahip ilk bilinen $\mathrm{Ni}$ hiperakkumülatör tür olduğu ifade edilmektedir (Sytar vd., 2013). Sooyeon vd. (2013b) çalışmalarında $\mathrm{ZnO}$ nanopartikül (NPs) ve mikropartiküllerin karabuğdayın 
bitki büyümesi, bioakümülasyon ve antioksidant enzim aktivitesine etkisini araştırdıklarında $2-10 \mathrm{mg} / \mathrm{L}$ konsantrasyonlarda önemli bir biyokütle azalması belirlemişlerdir. Çalışmamızda da $\mathrm{Cd}$ ve Ni uygulamasının biyokütle miktarını azalttığ 1 tespit edilmiştir. Eren ve Mert'in (2017) araştırma sonuçlarına göre bitkilerin artan dozlarda ağır metale bağlı olarak gösterdikleri en belirgin tepki, ürettikleri biyokütle miktarlarının azalması şeklinde ortaya çıkmıştır.

Tohum canlılık indeksi bitkinin erken gelişimi ve hızlı direnç oluşumu için önemli bir faktördür (Memon vd., 2013). Ashagre vd. (2014) aspir ile yaptıkları bir çalışmada belli bir bor düzeyinden sonra tohum canlılık indeksinin tüm çeşitlerde azalma gösterdiğini, ayrıca çeşitler arasında da farklılıkların olduğunu bildirmişlerdir. Aynı şekilde Mirshekari (2012) buğday üzerinde yaptığı çalışmada da bor konsantrasyonu arttıkça tohum canlılık indeksinin azaldığını belirtmiştir. Literatürde ağır metallerin Karabuğday tohumlarının canlılık indeksi üzerine etkisi ile ilgili herhangi bir çalışmaya rastlanmamıştır. Ahmad vd. (2012), Sehar-06, Fareed-06, Chakwal-50 ve Inqlab-91 olmak üzere 4 farklı buğday çeşidi ile yapmış oldukları çalışmada tüm çeşitlerin Cd tolerans indeksini belirlemişler; Cd tolerans indeksinin çeşitler arasında değişiklik gösterdiğini ve Sehar-06 çeşidinin $\mathrm{Cd}$ ile kirlenmiş topraklarda daha iyi çimlenebileceğini belirtmişlerdir. Ashagre vd. (2014) aspir ile yaptıkları çalışmada bor tolerans indeksinin, düşük bor seviyelerinde arttığını fakat bor konsantrasyonu yükseldikçe tolerans indeksinin azaldığını bildirmişlerdir. Shaikh vd. (2013) ise, buğday üzerine yaptıkları çalışmalarında bor konsantrasyonu arttıkça tolerans indeksinin azaldığını tespit etmişlerdir.
Sonuç olarak, $\mathrm{Cd}$ ve $\mathrm{Ni}$ uygulanan karabuğday bitkisinin, çalışılan dört farklı konsantrasyonda çimlenme oranı azalmış olsa da her iki metalden çok fazla etkilenmediği belirlenmiştir. Ancak taze-kuru ağırlık, biyokütle, kök uzunluğu ve canlılık tolerans indeksinin artan konsatrasyona bağlı olarak azaldığ1 özellikle yüksek konsantrasyonlarda bu azalmanın önemli olduğu tespit edilmiştir. Sağlıklı bir bitkinin yetiştirilmesinde kritik bir evre olan çimlenme ve fide gelişimi konusunda $\mathrm{Cd}$ ve $\mathrm{Ni}$ ile ilgili elde edilen bu veriler literatüre var olan farklı metallerle yapılmış çalışmalara katkı sağlayacaktır.

\section{Kaynaklar}

Acar, R. 2009. "Karabuğday (Köşeli Buğday)'ın Tarımı", Konya Ticaret Borsast Dergisi, 11(31) 30-37.

Acar, R., Güneş, A., Gummadov, N., Topal, İ. 2011. "Farklı Bitki Siklıklarının Karabuğdayda (Fagopyrum esculentum Moench) Verim ve Bazı Verim Unsurlarına Etkisi”, Selçuk Tarım ve Gıda Bilimleri Dergisi, 25(3): 47-51.

Ahmad, I., Akhtar, M. J., Zahir, Z. A., Jamil, A. 2012. "Effect of Cadmium on Seed Germination and Seedling Growth of Four Wheat (Triticum aestivum L.) Cultivars", Pak. J. Bot., 44(5): 1569-1574.

Alves, Jc., Souza, A. P., Porto, M. L. A., Fontes, R. L. F., Arruda, J., Marques, L. F. 2016. "Potential of Sunflower, Castor Bean, Common Buckwheat and Vetiver as Lead Phytoaccumulators", Revista Brasileira de Engenharia Agrícola e Ambiental, 20(3):243249.

Ashagre, H., Ibrahim, A., Hamza, T. 2014. "Urgecha Fita and Worku Nedesa, Influence of Boron on Seed Germination and Seedling Growth of Wheat (Triticum aestivum L.), Afr. J. Plant Sci., 8(2):133-139.

Ashraf, MY., Sadiq, R., Hussain, M., Ashraf, M., Ahmad, M. S. A., 2011. "Toxic Effect of Nickel (Ni) on Growth and Metabolism in 
Germinating Seeds of Sunflower (Helianthus annuus L.)", Biol. Trace. Elem. Res.,143:1695-1703.

Benavides, M. P., Gallego, S. M., Tomaro, M. L. 2005. "Cadmium Toxicity in Plants", Braz. J. Plant Physiol., 17(1): 21-34.

Bjorkman, T. 2010. "Buckwheat Production: Harvesting." Cornell University Cooperative Extension Agronomy Fact Sheet Series: Fact Sheet 51, Ithaca, NY.

Böhm, W. 1979." Methods of Studying Root Systems", Agricultural Systems, 6(3): 247248.

Christa, K., Smietana, M. 2008. "Buckwheat Grains and Buckwheat Products - Nutritional and Prophylactic Value of Their Components - A Review", Czech Journal Food Science, Vol. 26: 153- 162.

Dizlek, H., Özer, M. S., İnanç, E., Gül, H. 2009. "Karabuğday'ın (Fagopyrumes culentum Moench) Bileşimi ve Gida Sanayiinde Kullanım Olanakları", Gida, 34 (5): 317-324.

Ebru, O. G. 2014. "Nickel and Cobalt Effects on Mize Germination", 2nd International Conference on Agriculture and Biotechnology, IPCBEE, 79:62-65.

Erbaş M., Gül, S., Şekerci, H. 2008. "Fonksiyonel Gıda Bileşeni Olarak Diyetsel Antioksidanlar", Türkiye 10. Gıda Kongresi Bildiri Kitab1, Erzurum, 1053- 1056.

Eren, A., Mert, M. 2017. “A ve $\mathrm{Cu}$ ) Uygulamalarının Andız Otu, Fener Otu ve Sığır kuyruğu Bitkilerinin Büyüme ve Gelişmesi Üzerine Etkisi”, Turk. J. Agric. Res., 4(1): 50-58.

Finch-Savage, W. E., Leubner-Metzger, G. 2006. "Seed Dormancy and the Control of Germination," New Phytology, 171(3): 501523.

Franzaring, J., Damsohn, W., Fangmeier, A., Schlosser, S., Kurz, H., Büttner, P. 2018. "Phytotoxicity of Tin Mine Waste and Accumulation of Involved Heavy Metals in Common Buckwheat (Fagopyrum esculentum
Moench)", International Journal of Phytoremediation, 20(5): 462-470.

Gratao, L. P., Polle, A., Lea, P., Azevedo, A. 2005. "Making the Life of Heavy Metalstressed Plants a Little Easier", Functional Plant Biology, 32, 481-494.

Guan, Z., Chai, T., Zhang, Y., Xu, J., Wei, W. 2009. "Enhancement of Cd Tolerance in Transgenic Tobacco Plants Overexpressing a Cd-Induced Catalase cDNA", Chemosphere, 76 (5): 623-630.

Güneş, A., Topal, İ., Koç, H., Akçacık, A. G., Bayrak, H., Özcan, G., Taş, M. N., Acar, R. 2012. "Farklı Ekim Zamanlarının Karabuğday'da (Fagopyrum esculentum Moench.) Verim ve Bazı Verim Unsurlarına Etkisi”, Tibbi ve Aromatik Bitkiler Sempozyum Kitabı, Tokat, 10-14.

Guo, Y., Chen, F., Yang, L. Y., Huang, Y. 2007. "Analyses of Theseed Protein Contents on the Cultivated and Wild Buckwheat Fagopyrum esculentum Resources", Genet. Resour. Crop. Evol., 54: 1465-1472.

Guo, B., Liang, Y., Zhu, Y. 2009. "Does salicylic Acid Regulate Antioxidant Defense Systems, Cell Death, Cadmium Uptake and Partitioning To Acquire Cadmium Tolerance In Rice?", J. Plant Physiol., 166: 20-31.

Gür, N., Topdemir, A., Munzuroğlu, Ö., Çobanoğlu, D. 2004. “Ağır Metal İyonlarının $(\mathrm{Cu}+2, \mathrm{~Pb}+2, \mathrm{Hg}+2, \mathrm{Cd}+2)$ Clivia sp. Bitkisi Polenlerinin Çimlenmesi ve Tüp Büyümesi Üzerine Etkileri”, Firat Üniversitesi Fen ve Matematik Bilimleri Dergisi, 16(2), 177-182.

Haktanır, K., Arcak, S. 1998. "Çevre Kirliliği”, Ankara Üni. Ziraat Fak. Toprak Bölümü, Ankara Üni. Yayınları, Yayın No: 1503, Ders Kitab1, Ankara, 357-375.

He, J., Ren, Y., Zhu, C.i Jiang, D. 2008. "Effects of Cadmium Stress on Seed Germination, Seedling Growth and Seed Amylase Activities in Rice (Oryza sativa)", Rice Science, 15(4):319-325.

Hirayama, T., Shinozaki, K. 2010. "Research on Plant Abiotic Stress Responses in The 
Post-Genome Era: Past, Present and Future", The Plant Journal, 61:1041-1052.

Işık, G., Çalıseki, M. 2017. "Ecophysiological Effects of Porsuk River's Water and Boron Mine Wastewater on Cucumis Sativus L. Seeds", Acta Physica Polonica A, 132 (3): 746-748.

Jabeen, N., Ahmad, R. 2012. "Improvement in Growth and Leaf Water Relation Parameters of Sunflower and Safflower Plants With Foliar Application of Nutrient Solutions Under Salt Stress", Pak. J. Bot., 44(4):13411345 .

Jamil, M., Deog, B. L., Kwang, Y. J., Ashraf, M., Sheong, C. L., Eui, S. R. 2006. "Effect of Salt $(\mathrm{NaCl})$ Stress on Germination and Early Seedling Growth of Four Vegetables Species", Journal of Central European Agriculture, 7(2): 273-282.

Kaçar, B., Katkat, V. 2010. "Bitki Besleme", 5. Bask1, Nobel Yayıncılık, Ankara, 22-27.

Kan, A. 2014. "A New Plant for Turkey; Buckwheat (Fagopyrum esculentum)", Biological Diversity and Conservation, 7(2), 154-158.

Kantarc1, M. D. 2000. “Toprak İlmi”, İÜ Toprak İlmi ve Ekoloji Anabilim Dalı, $\dot{I U}$ Yayınları, No. 4261, İstanbul, 142-155.

Kayaçetin, F., Efeoğlu, B., Alizadeh, B. 2018. "Effect of $\mathrm{NaCl}$ and PEG-Induced Osmotic Stress on Germination and Seedling Growth Properties in Wild Mustard (Sinapis arvensis L.)", Anadolu J. of AARI, 28(1): 62-68.

Kranner,I., Colville, L. 2011. "Metals and Seeds: Biochemical and Molecular Implications and Their Significance for Seed Germination", Environmental and Experimental Botany, 72(1):93-105.

Laghmouchi, Y., Belmehdi, O., Bouyahya, A., Senhaji, N. S., Abrini, J. 2017. "Effect of temperature, salt stress and $\mathrm{pH}$ on seed germination of medicinal plant Origanum compactum", Biocatalysis and Agricultural Biotechnology, 10: 156-160.

Liu, Y., Yu, L., Chen, Y., Liu, X., Wu, L., Huang, J., He, S. 2006. "Lead tolerance of different Fagopyrum esculentum cultivars", Chinese Journal of Ecology, 25(11):13441347.

Liu, B., Zhang, K., Nie, H., Zhai, S. 2009. "Effect of Copper on Seed Germination and Seedling Growth of Fagopyrum esculentum Moench", Shandong Agricultural Sciences, 2009-09.

Liu, S., Yang, C., Xie, W., Xia, C., Fan, P. 2012. "The Effects of Cadmium on Germination and Seedling Growth of Suaeda salsa", Procedia Environmental Sciences 16: 293-298.

Madhava, R. K. V., Sresty, T. V. S. 2000. "Antioxidative Parameters in The Seedlings Of Pigeonpea (Cajanus Cajan L. Millspaugh) in Response to Zn and Ni Stresses", Plant Sci. 157, 113-28.

Marschner, H. 1995. "Mineral Nutrition of Higher Plants", Academic Press, London.

Memon, S. Q., Mirjat, M. S., Mughal, A. Q., Amjad, N. 2013. "Effect of Conventional and Non-Conventional Tillage Practices on Maize Production", Pak. J. Agri., Agril. Engg., Vet. Sci., 29(2):155-163.

Mirshekari, B. 2012. "Seed Priming With Iron and Boron Enhances Germination and Yield of Dill (Anethum graveolens)", Turk J. Agric. For., 36:27-33.

Mishra, D., Kar, M. 1974. "Nickel in Plant Growth and Metabolism", Botanical Review, 40:395-452.

Munzuroğlu, Ö., Geçkil, H. 2002. "Effects of Metals on Seed Germination, Root Elongation, and Coleoptile and Hypocotyl Growth in Triticum aestivum and Cucumis sativus", Arch. Environ. Contam. Toxicol., 43(2): 203-217.

Nasr, N. 2013. "Germination and Seedling Growth of Maize (Zea mays L.) Seeds in Toxicity of Aluminum and Nickel", Merit Research Journal of Environmental Science and Toxicology, 1(5):110-113.

Peng, L., Wang, S., Zou, L., Zhao, J., Zhao, G. 2012. "HPLC Fingerprint of Buckwheat from 
Different Habitats and Varieties", Phcog. Journal., Vol. 31: 5-10.

Rajbhandari, P. 2004. "Eco-physiological Aspects of Common Buckwheat", Proceedings of the 9th International Symposium on Buckwheat. 101-108. 2004, Prague.

Sandalio, L. M., Dalurzo, H. C., Gomez, M., Romero-Puertas, M. C., del Rio, L. A. 2001. "Cadmium Induced Changes in The Growth And Oxidative Metabolism of Peaplants", Journal of Experimental Botany, 52: 21152126.

Shaikh, I. R. S., Rafique, A. S., Shaikh, A. A. 2013. "Phytotoxic Effects of Heavy Metals Parveen Rajjak (Cr, Cd, Mn and Zn) on Wheat (Triticum aestivum L.) Seed Germination and Seedlings Growth in Black Cotton Soil of Nanded. India", Res. J. Chem. Sci., 3(6): 1423.

Skrabanja V., Elmstahl, H., Kreft, I., Bjorck, I. 2001. "Nutritional Properties of Starch in Buckwheat Products Studies in Vitro and in Vivo", J. Agr. Food. Chem., Vol. 49: 490-496.

Sooyeon, L., Hyein, C., Saeyeon, K., Insook, L. 2013a. "The Genotoxic Effect of $\mathrm{ZnO}$ and $\mathrm{CuO}$ Nanoparticles on Early Growth of Buckwheat, Fagopyrum esculentum", Water, Air, \& Soil Pollution, 224:1668.

Sooyeon, L., Sunghyun, K., Saeyeon, K., Insook, L. 2013b. "Assessment of Phytotoxicity of ZnO NPo on a medicinal plant, Fagopyrum esculentum", Environmental Science and Pollution Research, 20(2): 848-854.

Soudek, P., Katrusakova, A., Sedlacek, L., Petrova, S., Koci, V., Marsik, P., Griga, M., Vanek, T. 2010. "Effect of Heavy Metals on Inhibition of Root Elongation in 23 Cultivars of Flax (Linum usitatissimum L.)", Arch Environ Contam Toxicol., 59(2):194-203.

Süzer, S. 2007. "Karabuğday Tarımı ve Çölyak Hastalarının Beslenmesindeki Önemi”, http://www.tarimmerkezi.com/yazar

Sytar, O., Cai, Z., Brestic, M., Kumar, A., Prasad, M. N. V., Taran, N., Smetanska, I.
2013. "Foliar Applied Nickel on Buckwheat (Fagopyrum esculentum L.) Induced Phenolic Compounds as Potential Antioxidants", Clean - Soil, Air, Water, 41(11):1129-1137.

Tamura, H., Honda, M., Sato, T., Kamachi, H. 2005. "Pb Hyperaccumulation and Tolerance in Common Buckwheat", J. Plant Res., 118:355-359.

Toppi, L. S. D., Gabrielli, R. 1999. "Response to Cadmium in Higher Plants", Environ. Exp. Bot., 41: 105-30.

Tran, T. A., Popova, L. P. 2013. "Functions and Toxicity of Cadmium in Plants: Recent Advances and Future Prospects", Turk. J. Bot., 37: 1-13.

Tziourtzioumis, D., Demetriades, L., Zogou, O. and Stamatelos, A. M. 2009. "Experimental İnvestigation of The Effect of a B70 Biodiesel Blend On A Common-Rail Passenger Car Diesel Engine", Automobile Engineering, 223: 685-701.

Vitoria, A. P., Lea, P. J., Azevedo, R. A. 2001. "Antioxidant Enzymes Responses to Cadmium in Radish Tissues", Phytochemistry, (57), 701-710.

Waisberg, M., Joseph, P., Hale, B., Beyersmann, D. 2003. "Molecular and Cellular Mechanisms of Cadmium Carcinogenesis", Toxicology, 192: 95-117.

Wang, C. X., Mo, Z., Wang, H., Wang, J. Z., Cao, Z. H. 2003. "The Transportation, TimeDependent Distribution of Heavy Metals in Paddy Crops", Chemosphere, 50: 717-723.

Watanabe, M., Ohshita, Y., Tsushida, T. 1997. "Antioxidant Compounds from Buckwheat (Fagopyrum esculentum Moench) Hulls", Journal of Agricultural and Food Chemistry, 45, 1039-1044.

Yavuz, H. 2014. "Aydın Ekolojik Koşullarında Farklı Ekim Sıklığının Karabuğday'da (Fagopyrum esculentum moench.) Verim ve Bazı Kalite Özelliklerine Etkisi”, Yüksek Lisans Tezi, Adnan Menderes Üniversitesi Fen Bilimleri Enstitüsü, Aydın, 7-16. 
Yıldız, N. 2001. "Toprak Kirletici Bazı Ağır

Metallerin ( $\mathrm{Zn}, \mathrm{Cu}, \mathrm{Cd}, \mathrm{Pb}, \mathrm{Co}$ ve $\mathrm{Ni}$ )

Belirlenmesinde Kullanılan Yöntemler", Atatürk Üniversitesi Ziraat Fakültesi Dergisi,

32 (2): 207-213. 